\title{
KOMPETENSI PEDAGOGIK GURU DENGAN STRATEGI PEMBELAJARAN KREATIF PADA MATA PELAJARAN BAHASA INDONESIA DI SEKOLAH DASAR
}

\author{
Amalia Taufik ${ }^{1}$ dan Nurul Aini ${ }^{2}$ \\ Fakultas Tarbiyah dan Keguruan, Universitas Islam Negeri Mataram \\ Email: ${ }^{1}$ amaliataufik@uinmataram.ac.id, ${ }^{2}$ nurulaini@yahoo.com
}

\begin{abstract}
Abstrak: Kompetensi guru kreatif menyangkut kemampuan mengelola dan melaksanakan pembelajaran, memanfaatkan teknologi, melaksanakan evaluasi, dan pengembangan potensi peserta didik dengan baik. Melalui variasi pembelajaran, guru mampu menciptakan kegiatan pembelajaran yang kreatif di sekolah dasar. Penelitian ini merupakan penelitian deskriptif kualitatif dengan lokus di SD Islam Al-Muslimun Bunut Baok. Hasil penelitian menunjukkan bahwa (1) kompetensi pedagogik guru kelas $\mathrm{V}$ dengan strategi pembelajaran kreatif pada mata pelajaran bahasa Indonesia di SDI Al-Muslimun Bunut Baok, meliputi: pemahaman terhadap peserta didik, kemampuan mengelola dan melaksanakan pembelajaran, kemampuan memanfaatkan teknologi pembelajaran, dan kemampuan melaksanakan evaluasi, dan pengembangan potensi peserta didik; (2) terdapat beberapa kendala yang dihadapi guru dalam menciptakan kegiatan pembelajaran yang kreatif pada Mata Pelajaran Bahasa Indonesia pada kelas V di SD Islam Al-Muslimun Bunut Baok, yaitu: bahasa yang digunakan peserta didik masih menggunakan bahasa daerah, adanya kedekatan antara guru dengan peserta didik dari latar belakang tempat tinggal yang sama menjadi alasan para guru dengan peserta didik terkesan kurang serius dalam proses pembelajaran, karakter yang berbeda dari peserta didik, tidak tersedianya media pembelajaran di sekolah, dan kurangnya anggaran.
\end{abstract}

Kata kunci: Kompetensi Pedagogik, Strategi Pembelajaran Kreatif, Sekolah Dasar.

\section{PENDAHULUAN}

Masalah pendidikan merupakan kebutuhan yang sangat penting bagi kehidupan masyarakat, baik di negara yang sudah maju maupun di negara yang sedang berkembang, terutama dalam kemajuan ilmu pengetahuan dan teknologi. Maju mundurnya suatu bangsa dapat ditentukan oleh pendidikan yang ada di negara itu sendiri. Sebagai bangsa yang memiliki harkat dan martabat yang menghargai hasil perjuangan, sudah seharusnya tanggap terhadap perkembangan yang terjadi di era globalisasi ini. Menghadapi era global tersebut, kondisi ini dapat dipandang sebagai tantangan yang harus direspon dengan meningkatkan sumber daya manusia. ${ }^{1}$

Upaya perbaikan di bidang pendidikan merupakan suatu keharusan untuk selalu dilaksanakan agar suatu bangsa dapat maju dan berkembang seiring dengan kemajuan ilmu

${ }^{1}$ Hamzah. 2012. Profesi Kependidikan Problema, Solusi dan Reformasi Pendidikan di Indonesia. Jakarta: Bumi Aksara. hal. 3. 
pengetahuan dan teknologi. Upaya perbaikan di bidang pendidikan yang dilaksanakan, antara lain: penyempurnaan kurikulum, peningkatan kompetensi guru melalui penataranpenataran, perbaikan sarana-sarana pendidikan, dan lain-lain. Hal ini dilaksanakan untuk meningkatkan mutu pendidikan bangsa dan terciptanya manusia Indonesia seutuhnya.

Dalam Undang-Undang Sistem Pendidikan Nasional Nomor 20 Tahun 2003 bab II Pasal 3 diungkapkan bahwa tujuan Sistem Pendidikan Nasional adalah untuk membentuk kepribadian bermartabat dan mencerdaskan agar menjadi insan beriman, bertakwa kepada Tuhan Yang Maha Esa. Selain itu, Undang-Undang di atas merupakan landasan pemerintah untuk menentukan arah kebijakan yang terkait masalah kurikulum yang harus digunakan untuk setiap jenjang pendidikan agar tidak timbul kesenjangan untuk semua sekolah ${ }^{2}$. Oleh karena itu, pengembangan kompetensi guru dilakukan untuk mencapai tujuan tertentu secara efektif dan efisien. ${ }^{3}$

Kompetensi guru adalah seperangkat pengetahuan, keterampilan, dan perilaku yang harus dimiliki, dihayati, dan dikuasai oleh guru dalam melaksanakan tugas keprofesionalannya. Kompetensi tersebut memuat kompetensi kepribadian, pedagogik, profesional, dan sosial. Kompetensi pedagogik adalah kemampuan mengelola pembelajaran peserta didik. Kompetensi ini meliputi pemahaman terhadap peserta didik, perancangan dan pelaksanaan pembelajaran, evaluasi hasil belajar, dan pengembangan peserta didik untuk mengaktualisasikan berbagai potensi yang dimilikinya.

Penguatan kompetensi adalah kunci keberhasilan pembelajaran. Pembelajaran yang kreatif adalah pembelajaran yang memberi kesempatan kepada peserta didik untuk merancang, membuat, berkreasi, dan mengkomunikasikan gagasan, pendapat atau pikirannya melalui karya tertentu, baik secara tertulis. Kegiatan tersebut akan memuaskan rasa keingintahuan dan imajinasi peserta didik. Ditinjau dari kegiatan guru, pembelajaran kreatif adalah pembelajaran yang menuntut guru dalam mengembangkan kegiatan belajar yang beragam untuk peserta didik. ${ }^{4}$

Berdasarkan hasil studi pendahuluan di SD Islam Al-Muslimun Bunut Baok menunjukkan bahwa kompetensi yang dimiliki guru ketika proses pembelajaran Bahasa

2Abdurrahman Shaleh. 2005. Pendidikan Agama dan Pengembangan Watak Bangsa. Jakarta: PT Raja Grafindo Persada. hal. 16.

${ }^{3}$ Mulyasa. 2007. Standar Kompetensi dan Sertifikasi Guru, Bandung: PT Remaja Rosdakarya. hal. 26.

${ }^{4}$ Zainal Aqib. 2009. Belajar dan Pembelajaran di Sekolab Dasar. Bandung: CV. Yrama Widya. hal. 21-22. 
Indonesia tampak dari kecakapan membuat suasana kelas menjadi lebih hidup dan kreatif dalam proses pembelajaran. Kekreatifan proses pembelajaran dapat terlihat dari suasana kelas yang di dalamnya terdapat berbagai macam variasi media yang dibuat guru dan juga dinding kelas dipenuhi dengan hasil karya peserta didik. Dengan demikian, menjadi penting untuk melakukan kajian yang berjudul "Kompetensi Pedagogik Guru dengan Strategi Pembelajaran Kreatif pada Mata Pelajaran Bahasa Indonesia di Kelas V SD Islam AlMuslimun Bunut Baok Lombok Tengah Tahun Pelajaran 2018/2019”.

\section{LANDASAN TEORI}

\section{A. Kompetensi Guru}

\section{Pengertian Kompetensi Guru}

Menurut Kamus Besar Bahasa Indonesia, kompetensi berarti kewenangan (kekuasaan) untuk menentukan atau memutuskan sesuatu hal. Pengertian dasar kompetensi (competency), yaitu kemampuan atau kecakapan. ${ }^{5}$ Dalam Undang-Undang Republik Indonesia Nomor 14 Tahun 2005 tentang Guru dan Dosen, dijelaskan bahwa "Kompetensi adalah seperangkat pengetahuan, keterampilan, dan perilaku yang harus dimiliki, dihayati, dan dikuasai oleh guru atau dosen dalam melaksanakan tugas keprofesionalan". ${ }^{6}$

Proses belajar mengajar merupakan suatu proses yang mengandung serangkaian perbuata guru dan peserta didik atas dasar hubungan timbal balik yang berlangsung dalam situasi edukatif untuk mencapai tujuan tertentu. Dalam proses belajar mengajar tersirat adanya satu kesatuan kegiatan yang tidak terpisahkan antara peserta didik yang belajar dan guru yang mengajar. Agar proses pembelajaran dapat dilaksanakan efektif dan efisien, maka guru mempunyai tugas dan peranan yang penting dalam mengantarkan peserta didiknya mencapai tujuan yang diharapkan. Oleh karena itu, sudah selayaknya guru mempunyai berbagai kompetensi yang berkaitan dengan tugas dan tanggung jawabnya. Dengan

5Dendi Sugono. 2008. Kamus Besar Bahasa Indonesia Dengan EYD. Jakarta: PT Gramedia Pustaka Utama, 2008. hal. 120.

${ }^{6}$ E. Mulyasa, Standar Kompetensi..., hal. 25. 
kompetensi tersebut, maka akan menjadikan guru profesional, baik secara akademik maupun nonakadeamik ${ }^{7}$.

Masalah kompetensi guru merupakan hal urgensi yang harus dimiliki oleh setiap guru dalam jenjang pendidikan apapun. Guru yang harus mengajar tentu harus pula memiliki pribadi yang baik dan mampu melakukan miting secara social adjustment dalam masyarakat. Kompetensi sangat penting dalam rangka penyusunan kurikulum, ini dikarenakan kurikulum pendidikan haruslah disusun berdasarkan kompetensi yang dimiliki oleh guru. Tujuan program pendidikan, sistem penyampaian, evaluasi dan sebagainya, hendaknya direncanakan sedemikian rupa agar relevan dengan tuntutan kompetensi guru secara umum. Dengan demikian diharapkan guru tersebut mempu menjalankan tugas dan tanggung jawab sebaik mungkin.

\section{Kompetensi Pedagogik Guru}

Berdasarkan Undang-Undang Nomor 14 tentang Guru dan Dosen Pasal 10, menjelaskan bahwa kompetensi guru meliputi kompetensi pedagogik, kompetensi kepribadian, kompetensi profesional, dan kompetensi sosial. ${ }^{8}$ Dalam Standar Nasional Pendidikan, penjelasan Pasal 28 Ayat (3) Butir a dikemukakan bahwa kompetensi pedagogik adalah kemampuan mengelola pembelajaran peserta didik. Kompetensi ini meliputi pemahaman terhadap peserta didik, perancangan dan pelaksanaan pembelajaran, evaluasi hasil belajar, dan pengembangan peserta didik untuk mengaktualisasikan berbagai potensi yang dimilikinya.

Dalam bukunya, Ramayulis mengemukakan bahwa kompetensi pedagogik guru merupakan kemampuan guru dalam pengelolaan pembelajaran peserta didik yang sekurang-kurangnya meliputi: (1) pemahaman terhadap peserta didik; (2) kemampuan mengelola dan melaksanakan pembelajaran; (3) kemampuan memanfaatkan teknologi pembelajaran; (4) kemampuan melaksanakan evaluasi terhadap hasil belajar; dan (5) pengembangan peserta didik untuk mengaktualisasikan berbagai potensi yang dimilikinya.

7Oemar Hamalik. 2006. Pendidikan Guru Berdasarkan Pendidikan Kompetensi, Jakarta: Bumi Aksara. hal. ${ }^{8}$ Mulyasa, Standar Kompetensi..., hal. 75. 


\section{B. Pembelajaran Kreatif}

\section{Pengertian Pembelajaran}

Kata pembelajaran merupakan perpaduan dari dua aktivitas, yaitu belajar dan mengajar. Aktivitas belajar secara metodologis cendrung lebih dominan pada peserta didik, sementara mengajar secara instruksional dilakukan oleh guru. Jadi, istilah pembelajaran adalah ringkasan dari kata belajar dan mengajar. Dengan kata lain, pembelajaran adalah penyederhanaan dari kata belajar mengajar, proses belajar mengajar atau kegiatan belajar mengajar. ${ }^{9}$ Dengan kata lain, pembelajaran adalah proses untuk membantu peserta didik agar dapat belajar dengan baik. Namun, dalam implementasinya, sering sering kali kata pembelajaran ini diidentikkan dengan kata mengajar.

Pada hakikatnya mengajar bukan sekadar menyampaikan materi pelajaran, tetapi juga proses mengatur lingkungan supaya peserta didik belajar. Makna mengajar yang demikian sering diistilahkan dengan pembalajaran. Ini mengisyaratkan bahwa dalam proses belajar mengajar peserta didik harus dijadikan sebagai pusat dari kegiatan pembelajaran. Hal ini dimaksudkan untuk membentuk watak, peradaban, dan meningkatkan mutu kehidupan peserta didik. ${ }^{10}$. Menurut Usman, pembelajaran merupakan suatu proses yang mengandung serangkaian perbuatan guru dan peserta didik, atas dasar hubungan timbal balik yang berlangsung dalam situasi edukatif, untuk mencapai tujuan tertentu. Proses pembelajaran merupakan interaksi semua komponen atau unsur yang terdapat dalam pembelajaran, yang satu sama lain saling berhubungan dalam sebuah rangkaian untuk mencapai tujuan. ${ }^{11}$

Dari uraian di atas, peneliti dapat menyimpulkan bahwa kegiatan pembelajaran adalah suatu proses yang mengandung serangkaian kegiatan guru dan peserta didik atas dasar hubungan timbal balik yang berlangsung dalam situasi edukatif untuk mencapai tujuan tertentu.

${ }^{9}$ Ahmad Susanto. 2016. Teori Belajar \& Pembelajaran di Sekolah Dasar. Jakarta: Prenadamedia Group, 2016. hal. 18.

${ }^{10}$ Hamruni, Strategi Pembelajaran, (Yogyakarta: Insan Madani, 2012), hal. 44.

11Jamal Ma'mur Asmani. 2012. 7 Tips Aplikasi P AKEM. Jogjakarta: Diva Press. hal. 30. 


\section{Pembelajaran Kreatif}

Pada dasarnya pengertian kreatif berhubungan dengan penemuan sesuatu mengenai hal yang menghasilkan sesuatu yang baru dengan menggunakan sesuatu yang telah ada ${ }^{12}$. Kreativitas maksudnya adalah menyangkut sesuatu paling penting dalam kehidupan manusia dan berkaitan dengan potensi yang ada dalam diri manusia yang dapat dimanfaatkan untuk mengubah kehidupan. Kata ini berhubungan dengan daya hebat yang berperan yang menciptakan hal-hal baru yang belum pernah ada sebelumnya. ${ }^{13}$

Dari uraian di atas dapat disimpulkan bahwa kreatif adalah kemampuan seseorang untuk melahirkan sesuatu yang baru dan memodifikasi sesuatu masalah yang sudah lama, sehingga mampu mengembangkan hal-hal yang sudah ada untuk memberikan sejumah pengetahuan terhadap peserta didik di sekolah, sehingga menjadi kesatuan aksi yang diterima.

\section{METODE PENELITIAN}

Penelitian ini merupakan penelitian kualitatif. Penelitian kualitatif ini adalah penelitian yang bersifat alami, yang digunakan untuk mendapatkan data yang mendalam yang lebih menekankan pada data yang sebenarnya. Di samping itu, data dari penelitian kualitatif ini dinyatakan dalam keadaan sewajarnya, atau sebagaimana adanya (natural setting) dengan tidak berubah dalam bentuk simbol-simbol atau bilangan.

Untuk mendapatkan data-data yang akurat dan sesuai dengan tujuan penelitian diperlukan sumber data yang akurat. Sumber-sumber data dalam penelitian ini adalah "sumber data Primer dan sumber data Sekunder."14 Data Primer, dalam penelitian ini adalah langsung dari objek penelitian. Data lapangan ini diperoleh langsung dari: Kepala SD Islam Al-Muslimun; (2) Guru kelas V SD Islam Al-Muslimun; (3) Peserta didiksiswi kelas V. Selanjutnya, data sekunder dalam penelitian ini berupa dokumentasi tertulis berupa foto-foto, catatan terkait dengan data guru, data peserta didik, data sarana prasarana dan struktur organisasi SD Islam Al-Muslimun Bunut Baok.

\footnotetext{
12Utami Munandar. 2002. Kreativitas dan Keberbakatan Strategi Mewujudkan Potensi Kreatif dan Bakat. Jakarta: Gramedia Pustaka. hal. 24.

13Utami Munandar. 2002. Kreativitas dan Keberbakatan Strategi Mewujudkan Potensi Kreatif dan Bakat, Jakarta: Gramedia Pustaka. hal. 24.

${ }^{14}$ Saefudin Azwar. 2010. Metode Penelitian. Yogyakarta: Pustaka Pelajar. hal. 91. 
Teknik analisis data penelitian model interaktif yang dikemukakan oleh Miles dan Huberman dalam Sugiyono, yaitu: aktivitas dalam analisis data kualitatif dilakukan secara interaktif dan berlangsung secara terus menerus sampai tuntas, sehingga datanya sudah jenuh. Aktivitas dalam analisis data, yaitu data reduction, data display, dan conclusion drawing/verification.

\section{HASIL PENELITIAN DAN PEMBAHASAN}

\section{A. Kompetensi Pedagogik Guru dengan Strategi Pembelajaran Kreatif pada Mata Pelajaran Bahasa Indonesia}

\section{Pemahaman Peserta Didik}

Proses pembelajaran Bahasa Indonesia sesuai dengan karakteristik anak. Karakteristik setiap anak memang berbeda-beda. Hal itu merupakan hal yang lumrah karena dalam pandangan guru perbedaan individual merupakan karakteristik peserta didik. ${ }^{15}$ Sri Rahayu dalam wawancaranya menyampaikan sebagai berikut:

"Setiap peserta didik mempunyai kemampuan yang berbeda, ada yang mudah memahami pelajaran, dan ada yang sulit untuk memahami pelajaran, maka ada perlakuan khusus dari guru agar semua peserta didik dapat memahami pelajaran dengan baik, untuk anak-anak yang lebih sulit memahami pelajaran, biasanya guru lebih memfokuskan perhatian pada anak-anak tersebut. Misalnya, dalam proses pembelajaran Bahasa Indonesia di kelas $\mathrm{V}$ ketika membuat puisi tidak semua peserta didik bisa membuat puisi, ketika guru melihat peserta didik yang tidak bisa maka saya bersikap telaten datang ke tempat duduk peserta didik untuk membimbingnya."16

\section{Kemampuan Guru dalam Mengelola dan Melaksanakan Pembelajaran}

Hasil observasi guru dalam mengelola dan melaksanakan pembelajaran sudah sesuai dengan tahapan-tahapan dalam rencana pembelajaran yang sudah ditentukan. ${ }^{17}$ Pelaksanaan pembelajaran dilakukan sesuai dengan kaidah pengembangan pembelajaran. Hasil wawancara dengan dengan guru kelas $\mathrm{V}$ mengatakan seperti ini:

"Sebelum melakukan proses pembelajaran biasanya dimulai dengan mengulang materi pelajaran sebelumnya dengan tujuan agar peserta didik mengingat dan mau belajar tentang materi yang telah diberikan sebelumnya. Dengan memberikan pertanyaan dari

${ }^{15}$ Observasi, 1 April 2019

${ }^{16}$ Dewi, Guru Kelas V SD Islam Al-Muslimun, Wawancara, Tanggal 1 April 2019

${ }^{17}$ Observasi, Tanggal 1 April 2019 
materi sebelumnya maka peserta didik terdorong untuk mau mengulang dan belajar materi sebelumnya. Juga dalam proses pembelajaran sering menggunakan metode pembelajaran yang beragam, seperti metode diskusi kelompok, demonstrasi, ceramah, juga penugasan."18

Senada dengan Ibu di atas, Bapak Hafizi menjelaskan bahwa beliau menyampaikan materi dengan jelas, sehingga mereka mudah memahami materi pelajaran dengan menggunakan metode diskusi kelompok, mereka lebih bersemangat dan antusias untuk belajar. ${ }^{19}$

\section{Kemampuan Memanfaatkan Teknologi Pembelajaran}

Berdasarkan hasil observasi yang telah dilakukan bahwa guru telah memanfaatkan media pembelajaran, akan tetapi belum maksimal, misalnya dalam penggunaan proyektor, alat tersebut memang ada, akan tetapi tidak setiap Mata Pelajaran Bahasa Indonesia menggunakannya. Hanya digunakan jika ada video yang ingin ditampilkan guru. ${ }^{20}$

Seperti yang diungkapkan Kepala SD Islam Al-Muslimun, Bapak Irham Hadi:

"Seorang guru harus memiliki kemampuan di bidang teknologi. Di sekolah sudah sediakan Proyektor dan laptop, namun guru tidak selalu menggunakannya, hanya pada materi tertentu saja. Misalkan penggunaan proyektor hanya saat guru ingin menampilkan video dan gambar dalam kegiatan pembelajaran."21

Hal senada juga dikatakan oleh guru kelas V bahwa sebagai seoarang guru tentu harus bisa memanfaatkan teknologi dalam kegiatan pembelajaran, karena peran teknologi juga bisa membangkitkan semangat belajar peserta didik peserta didik, misalnya ketika menampilkan video atau gambar yang menarik menggunakan proyektor, antusias peserta didik luar biasa. ${ }^{22}$

\section{Kemampuan Melaksanakan Evaluasi Hasil Belajar}

Tampak pada aktivitas guru kelas V melakukan ulangan harian, ulangan MID semester dan ulangan akhir dengan RPP yang telah ada. Ulangan tersebut berbentuk tes dan nontes. Ulangan tes yaitu dengan pilihan ganda dan soal uraian, sedangkan bentuk nontes adalah penilaian sikap. Penilaian sikap tersebut akan digabungkan dengan hasil penilaian tertulis.

\footnotetext{
18Dewi, Guru Kelas V SD Islam Al-Muslimun, Wawancara, Tanggal 1 April 2019

${ }^{19}$ Uswatun, Siswa Kelas V, WawancaraI, Tanggal 1 April 2019

${ }^{20}$ Observasi, 1 April 2019

${ }^{21}$ Irham Hadi, Kepala Sekolah SD Islam Al-Muslimun, Wawancara, Tanggal 1 April 2019

22Dewi, Guru Kelas V SD Islam Al-Muslimun, Wawancara, Tanggal 1 April 2019
} 
Penilaian hasil belajar guru kelas $\mathrm{V}$ terkait dengan bagaimana peserta didik dapat memahami materi dengan baik dan bagaimana perilaku peserta didik dalam kehidupan sehari-hari di sekolah. ${ }^{23}$ Hal senada juga diungkapkan oleh Bapak Irham Hadi bahwa dalam kegiatan pembelajaran Bu Dewi melakukan penilaian dengan cara penilaian kelas. Di mana Bu Dewi melakukan ulangan harian, ulangan umum dan ujian akhir.

\section{Pengembangan potensi peserta didik}

Dengan kompetensi pedagogik guru, guru dapat mengembangkan potensi peserta didik melalui berbagai cara, antara lain: kegiatan ekstrakurikuler, pengayaan, remedial, dan bimbingan konseling. Dengan kompetensi tersebut, guru kelas V di SDI Al-Muslimun selalu berusaha mengembangkan potensi yang terdapat dalam diri peserta didik sehingga dapat membantu peserta didik untuk mau bertindak dan berpikir kreatif. Dengan menggunakan metode yang beragam dan melatih peserta didik untuk mau berpikir, guru telah menciptakan kegiatan pembelajaran yang kreatif di sekolah. ${ }^{24}$

\section{B. Kendala Guru dalam Menciptakan Kegiatan Pembelajaran yang Kreatif}

Sudah menjadi hukum alam dalam setiap kegiatan yang dilakukan, tidak mungkin akan selalu berjalan mulus seperti apa yang direncanakan, pasti ada kendala-kendala yang dihadapi. Seperti halnya dalam proses belajar mengajar di setiap lembaga pendidikan tidak terkecuali di SDI Al-Muslimun Bunut Baok.

Sesuai dengan hasil observasi yang peneliti lakukan, terdapat kendala yang dihadapi guru dalam menciptakan kegiatan pembelajaran yang kreatif pada mata pelajaran bahasa Indonesia di kelas V SDI Al-Muslimun Bunut Baok adalah sebagai berikut:

1. Masih banyak peserta didik yang melakukan komunikasi menggunakan bahasa ibu bukan bahasa Indonesia sehingga pada saat mengajar berbahasa Indonesia

2. Adanya kedekatan antara guru dengan murid dari latar belakang tempat tinggal yang sama menjadi alasan para guru dengan peserta didik terkesan kurang serius dalam proses pembelajaran, sering menghiraukan perintah guru, serta kurang bersemangat dalam belajar. ${ }^{25}$

\footnotetext{
23Dewi, Guru Kelas V SD Islam Al-Muslimun, Wawancara, Tanggal 1 April 2019

${ }^{24}$ Observasi, 1 April 2019

${ }^{25}$ Observasi, 27 Mei 2019
} 
3. Variasi kecerdasan dari tiap-tiap peserta didik yang berbeda. Ada yang byper active dan ada juga yang pasif, ada yang mudah paham dan ada yang sulit memahami materi pelajaran. ada peserta didik yang pendiam yang sulit diajak berbicara, ada peserta didik yang byper active yang tidak bisa diam, ada yang tidak bisa fokus dan sulit diajak berbicara, ada yang mudah paham, juga ada yang sulit memahami materi pelajaran, ini tentu akan menjadi kendala tersendiri baik bagi guru maupun peserta didik dalam menciptakan proses pembelajaran yang kreatif. 26

4. Tidak tersedianya media pembelajaran di sekolah.

5. Kurangnya anggaran.

\section{PEMBAHASAN}

\section{A. Kompetensi Guru dan Pembelajaran yang Kreatif}

Sebagai pendidik, guru harus memiliki kemampuan dan kecakapan dalam mengajar. Kemampuan dan kecakapan merupakan modal dasar bagi seorang guru dalam melaksanakan tugasnya sebagai pendidik. Oleh karena itu, guru sangat dituntut untuk menjadi guru yang profesional yang memiliki berbagai kompetensi. ${ }^{27}$ Kompetensi guru adalah seperangkat pengetahuan, keterampilan, dan prilaku yang harus dimiliki, dihayati, dan dikuasai oleh guru dalam melaksanakan tugas keprofesionalannya.

Kompetensi merupakan komponen utama dari standar profesi di samping kode etik sebagai regulasi perilaku profesi yang ditetapkan dalam prosedur dan sistem pengawasan tertentu. Kompetensi diartikan sebagai perangkat perilaku efektif yang terkait dengan eksplorasi, investigasi, menganalisis dan mempersepsi yang mengarahkan seseorang menemukan cara-cara untuk mencapai tujuan tententu secara efektif dan efisien.

Kompetensi pedagogik adalah kemampuan mengelola pembelajaran peserta didik. Kompetensi ini meliputi pemahaman terhadap peserta didik, perancangan dan pelaksanaan pembelajaran, evaluasi hasil belajar, dan pengembangan peserta didik untuk mengaktualisasikan berbagai potensi yang dimilikinya. Dalam bukunya Mulyasa mengemukakan bahwa dalam Standar Nasional Pendidikan pasal 28 ayat 3, yang dimaksud dengan kompetensi pedagogik adalah kemampuan mengelola pembelajaran peserta didik

${ }^{26}$ Dewi, Guru Kelas V SDI Al Muslimun, Wawancara, Tanggl 1 April 2019

${ }^{27}$ Mulyasa, Standar Kompetensi..., hal. 6. 
yang meliputi pemahaman terhadap peserta didik, perancangan dan pelaksanaan pembelajaran, evaluasi hasil belajar, dan pengembangan peserta didik untuk mengaktualisasikan berbagai potensi yang dimilikinya.

Ada 5 komponen dalam kompetensi pedagogik yang dimiliki oleh guru kelas V di SD Islam Al-Muslimun Bunut Baok yaitu :

\section{Pemahaman terhadap peserta didik}

Peserta didik memiliki karakteristik dan kemampuan yang berbeda beda, baik dipandang dari segi kreativitas dan kemampuannya pula berbeda-beda. Oleh sebab itu, guru kelas V SD Islam Al Muslimun memberi tanda pada absensi yang mereka pegang tentang daftar peserta didik yang memiliki kemampuan tinggi maupun yang memiliki kemampuan rendah. Dengan memahami tingkat kemampuan peserta didik, guru mengatur strategi pembelajaran sehingga tujuan dari kegiatan pembelajaran dapat tercapai sesuai dengan tujuannya.

Dalam kegiatan pembelajaran di kelas V SD Islam Al Muslimun menggunakan beberapa strategi pembelajaran yang sesuai dengan karakteristik peserta didik. misalnya guru membagi anak menjadi beberapa kelompok yang terdiri dari anak yang aktif di kelas dan anak yang kurang aktif di kelas sehingga dalam menyampaikan materi dapat sesuai dengan kemampuan anak dan karakternya masing-masing. Dengan demikian, anak di kelas dalam menyerap materi bisa lebih mudah mengerti dan memahami materi.

Pemahaman peserta didik merupakan salah satu kompetensi pedagogik yang harus dimiliki guru. Sedikitnya terdapat empat hal yang harus dipahami guru dan peserta didiknya. Pemahaman terhadap peserta didik mencakup berbagai aspek, antara lain: tingkat kecerdasan, kreativitas, kondisi fisik, perkembangan dan potensi peserta didik di SD Islam Al Muslimun pada umumnya tidak jauh berbeda dengan sekolah lain. Terdapat tiga tingkat kecerdasan yaitu, di bawah rata-rata, rata-rata, dan di atas rata-rata.

Dalam menangani hal tersebut, guru kelas $\mathrm{V}$ memakluminya. Beliau menganggap bahwa hal tersebut merupakan hal yang wajar dan sering dihadapai oleh banyak guru. Seoarng guru harus bersukap bijak dalam menghadapi hal tersebut, tidak pilih kasih, justru selalu memberikan motivasi. Penanganan peserta didik yang di bawah rata-rata, guru kelas 
$\mathrm{V}$ tidak memaksakan suatu materi dalam waktu yang singkat, justru guru memantau secara terus menerus sekaligus selalu memberikan motivasi agar minat dan semangat belajar tidak kurang. Setiap memberikan nasihat guru selalu melihat situasi dan kondisi agar peserta didik tersebut tidak merasa malu dan minder.

Untuk peserta didik yang di atas rata-rata guru memperlakukannya sama dengan peserta didik lain yang di bawah rata-rata. Diharapkan agar tidak terdapat perbedaan, walau terkadang guru harus memberikan reward kepada peserta didik yang berprestasi. Dengan memberikan penghargaan maka peserta didik tersebut akan semakin termotivasi untuk lebih baik lagi. Penghargaan tersebut juga diharapkan dapat memotivasi peserta didik lain yang kurang berprestasi agar terus meningkatkan prestasinya.

Selain dengan tingkat kecerdasannya, aspek lain adalah kreativitas. Tidak semua peserta didik yang pandai adalah peserta didik yang kreatif. Oleh karena itu, dalam mengembangkan kreativitas, guru memberikan peluang yang sama kepada semua peserta didik.

\section{Kemampuan mengelola dan melaksanakan pembelajaran}

Pembelajaran pada hakikatnya adalah proses interaksi antara peserta didik dengan lingkungan, sehingga terjadi perilaku ke arah yang lebih baik. ${ }^{28}$ Perencanaan pembelajaran di kelas menurut guru kelas V SD Islam Al-Muslimun telah merencanakan jauh sebelumnya baik itu memilih, menetapkan dan mengembangkan metode pembelajaran sehingga guru harus terlebih dahulu mengetahui kebutuhan yang harus dipenuhi kompetensi yang ingin dicapai agar sesuai dengan apa yang diharapkan. Oleh sebab itu, guru harus membuat silabus dan rencana pelaksanaan pembelajaran (RPP) setiap awal masuk semester sehingga kesiapan mengajarnya lebih jauh disiapkan sebelumnya sehingga dalam menghadapi peserta didik di kelas tinggal mempraktikkannya.

Mengajar secara kreatif sangat bergantung pada pemilihan dan penggunaan metode mengajar yang serasi dengan tujuan mengajar. metode-metode tersebut sangat menentukan pemahaman peserta didik, karena tanpa adanya strategi dan metode yang dilakukan di kelas, maka peserta didik dalam memahami materi akan mengalami kesulitan akan tetapi jika metode tersebut dapat diterapkan dengan baik maka peserta didik dalam memahami

${ }^{28}$ Ibid., hal. 92-94.

12 Copyright (C) el-Midad : Jurnal PGMI 2019 
pelajaran akan lebih mudah. ${ }^{29}$ Metode mengajar yang dilakukan oleh guru kelas V di SD Islam Al-Muslimun di antaranya: ceramah, demonstrasi, tanya jawab, penugasan, kerja kelompok, dan latihan.

\section{Kemampuan memanfaatkan teknologi pembelajaran}

Dalam menyelenggarakan pembelajaran, guru menggunakan teknologi sebagai media. Menyediakan bahan belajar dan mengadministrasikan dengan menggunakan teknologi informasi. Membiasakan anak berinteraksi dengan menggunakan teknologi. Fasilitas pendidikan pada umumnya mencakup sumber belajar, sarana dan prasarana sehingga peningkatan fasilitas pendidikan harus ditekankan pada peningkatan sumber belajar, baik kuantitas maupun kualitasnya, sejalan dengan perkembangan teknologi pendidikan. Dalam memanfaatkan teknologi yang ada, guru kelas V sudah memanfaatkannya akan tetapi belum maksimal. Karena dalam penggunaannya tidak setiap mata pelajaran menggunakannya. Misalnya dalam penggunaan proyekor. Alat tersebut memang ada di sekolah, akan tetapi tidak setiap materi pelajaran bahasa Indonesia menggunakannya, dengan alasan proyektor dipakai oleh guru yang lain, tetapi untuk mensiasati ketidaksediaan proyektor, guru membuat atau merancang sendiri media yang dibutuhkan. Misalnya, media gambar dan lain sebagainya.

\section{Kemampuan melaksanakan evaluasi terhadap hasil belajar}

Evaluasi adalah proses pengukuran atau penilaian. Berhasil tidaknya suatu pendidikan dalam mencapai tujuannya dapat dilihat dari evaluasi terhadap output yang dihasilkan. Dengan kompetensi yang dimilikinya, maka setiap guru harus mengadakan evaluasi setelah materi yang diajarkan selesai. ${ }^{30}$ Evaluasi hasil belajar dilakukan untuk mengetahui perubahan dan pembentukan kompetensi peserta didik, yang dapat dilakukan dengan penilaian kelas, tes kemampuan dasar, penilaian akhir satuan pendidikan dan sertifikasi, serta penilaian program. Pada saat mau mengakhiri materi pelajaran memberikan evaluasi terhadap peserta didik menggunakan cara yang berbeda-beda. Untuk menevaluasi dari apa

${ }^{30}$ Ramayulis. 2016. Profesi dan Etika Keguruan. Jakarta: Kalam Mulia, 2016. hal. 93 
yang telah dipelajari, maka guru memberikan beberapa tugas kepada peserta didik rumahnya.

Dalam penilaian guru kelas V di SD Islam Al-Muslimun lebih fokus kepada penilaian kognitif, afektif, dan psikomotorik. Dalam penilaian ini dapat diambil dari tes dan nontes. Tes dibagi menjadi beberapa macam diantaranya, tes tertulis, tes lisan, tes uraian, dan penugasan, sedangkan nontes merupakan penialaian yang diambil dari sikap keseharian peserta didik.

\section{Pengembangan peserta didik untuk mengaktualisasikan berbagai potensi yang dimilikinya}

Pengembangan peserta didik merupakan bagian dari kompetensi pedagogik yang harus dimiliki guru, untuk mengaktualisasikan berbagai potensi yang dimiliki peserta didik. pengembangan peserta didik dapat dilakukan oleh setiap guru melalui berbagai cara, antara lain: kegiatan ekstrakurikuler, pengayaan dan remedial, serta bimbingan konseling. Dengan sikap guru kelas V di SDI Al-Muslimun yang selalu berusaha mengembangkan potensi yang terdapat dalam diri peserta didik, maka hal ini membantu peserta didik untuk mau bertindak dan berpikir kreatif. Dengan menggunakan metode yang beragam dan melatih peserta didik untuk mau berpikir, maka akan dapat menunjang tercapainya kegiatan pembelajaran yang kreatif di sekolah.

Kompetensi guru kelas $\mathrm{V}$ di SDI Al-Muslimun dalam kegiatan pembelajaran diaktualisasikan melalui kemampuan menjadi fasilitator belajar dengan memberikan tantangan-tantangan yang membuat peserta didik semakin antusias dalam melakukan kegiatan belajarnya sehingga menjadi proses pembelajaran yang kreatif.

Kompetensi pedagogik dari seorang pendidik merupakan modal dasar bagi pendidik yang bersangkutan dalam menjalankan tugas keguruannya secara profesional. Kegiatan pendidikan pada dasarnya merupakan suatu proses penyelenggaraan pembelajaran yang mendidik. ${ }^{31}$ Proses pembelajaran pada hakikatnya untuk mengembangkan aktivitas dan kreativitas peserta didik, melalui berbagai interaksi dan pengalaman belajar. Secara umum, guru menciptakan kondisi belajar yang baik, yang memungkinkan peserta didik dapat mengembangkan kreativitasnya.

${ }^{31}$ Ramayulis, Profesi..., h. 93 
Pembelajaran kreatif adalah pembelajaran yang mewadahi pikiran, gagasan dan kreativitas peserta didik. Ditinjau dari kegiatan peserta didik, pembelajaran yang kreatif adalah pembelajaran yang memberi kesempatan kepada peserta didik untuk merancang, membuat, berkreasi, dan mengkomunikasikan gagasan, pendapat atau pikirannya melalui karya tertentu, baik secara tertulis maupun tidak tertulis. Kegiatan tersebut akan memuaskan rasa keingintahuan dan imajinasi peserta didik. Ditinjau dari kegiatan guru, pembelajaran kreatif adalah pembelajaran yang menuntut guru dalam mengembangkan kegiatan belajar yang beragam untuk peserta didik. ${ }^{32}$

Kompetensi pedagogik guru kelas V di SDI Al-Muslimun dicerminkan dalam bentuk kegiatan pembelajaran yang mampu membuat peserta didik belajar dengan antusias lebih bersemangat. Dengan keadaan peserta didik seperti ini, maka akan sangat membantu bagi guru kelas $\mathrm{V}$ dalam upaya menciptakan proses pembelajaran yang kreatif.

\section{B. Kendala guru dalam menciptakan kegiatan pembelajaran yang kreatif}

Sudah menjadi hukum alam dalam setiap kegiatan yang dilakukan, tidak mungkin akan selalu berjalan mulus seperti apa yang direncanakan, pasti ada kendala-kendala yang dihadapi. Seperti halnya dalam proses belajar mengajar disetiap lembaga pendidikan tidak terkecuali di SDI Al-Muslimun Bunut Baok. Kendala-kendala yang dihadapi guru dalam mengimplementasikan kompetensi sosial guru dalam menciptakan kegiatan pembelajaran yang menyenangkan pada mata pelajaran aqidah akhlak pada kelas V di SDI Al-Muslimun Bunut Baok adalah sebagai berikut:

\section{Bahasa}

Pada masa sekolah ini anak menyadari bahwa bahasa merupakan alat komunikasi yang penting untuk menyampaikan maksud, keinginan, dan kebutuhannya kepada orang lain. Selain itu, berbicara sebagai salah satu bentuk bahasa merupakan sarana penting untuk memperoleh tempat dalam kelompoknya. ${ }^{33}$ Adanya kedekatan antara guru dengan murid dari latar belakang tempat tinggal yang sama menjadi alasan para guru dengan peserta didik terkesan kurang serius dalam proses pembelajaran.

32Zainal Aqib, Belajar dan Pembelajaran..., h. 21-22.

${ }^{33}$ Soetjiningsih. 2012. Psikologi Perkembangan Anak. Jakarta: PRENADA, 2012. hal. 261. 


\section{Karakter yang berbeda dari masing-masing peserta didik.}

Karakteristik peserta didik adalah aspek-aspek atau kualitas perseorangan peserta didik seperti bakat, motivasi dan hasil belajar yang telah dimilikinya. ${ }^{34}$ Berbedanya karakter masing-masing peserta didik memang suatu hal yang lumrah adanya, namun secara tidak langsung akan menjadi kendala lancarnya proses belajar mengajar. Guru sangat perlu memahami karakter peserta didik, karena setiap peserta didik memiliki kemampuan yang unik dan mempunyai karakteristik yang berbeda-beda.

\section{Tidak tersedianya media pembelajaran di sekolah}

Media merupakan alat bantu dalam proses pembelajaran yang dapat memperjelas materi yang disampaikan guru. Dengan menggunakan media dalam proses pembelajaran juga mampu untuk lebih menarik perhatian dan minat belajar peserta didik. Ketika fungsi media pengajaran itu diaplikasikan dalam proses belajar mengajar, maka terlihat peranannya sebagai berikut:

a. Media yang digunakan guru sebagai penjelas dari keterangan terhadap suatu bahan yang guru sampaikan

b. Media dapat memunculkan permasalahan untuk dikaji lebih lanjut dan dipecahkan oleh para peserta didik dalam proses pembelajaran

c. Media sebagai sumber belajar bagi peserta didik, media sebagai bahan konkret berisikan bahan-bahan yang harus dipelajari para peserta didik, baik individual maupun kelompok. Kekonkretan sifat media akan banyak membantu tugas guru dalam kegiatn belajar mengajar. ${ }^{35}$

\section{Kurangnya anggaran}

Anggaran sangat dibutuhkan untuk keberhasilan dalam proses belajar mengajar. Dalam upaya menciptakan kegiatan pembelajaran yang kreatif membutuhkan anggaran yang cukup besar agar dapat menunjang fasilitas belajar kreatif peserta didik.. Anggaran sangat dibutuhkan untuk menggerakkan program. Kekuatan anggaran bisa mendinamisir kegiatan. Aplikasi dalam pembelajaran yang aktif dan kreatif membutuhkan anggaran yang besar, karena fasilitas buku, ruangan, dan lainnya menjadi keniscayaan. Penataan lingkungan dan

34Hamzah B. Uno. 2011. Perencanaan Pembelajaran. Jakarta: PT Bumi Aksara, 2011. hal. 20.

35Pupuh Fathurrohman. 2014. Strategi Belajar Mengajar. Bandung: Refika Aditama, 2014. hal. 66-67.

16 Copyright (C) el-Midad : Jurnal PGMI 2019 
dukungan publik membutuhkan pemantapan secara terus menerus, baik intensif maupun ekstensif. 36

\section{SIMPULAN DAN SARAN}

\section{Simpulan}

Berdasarkan hasil penelitian dan pembahasan, peneliti dapat menarik kesimpulan bahwa kompetensi pedagogik guru kelas V dengan strategi pembelajaran kreatif pada Mata Pelajaran Bahasa Indonesia di SDI Al-Muslimun Bunut Baok, antara lain: (1) pemahaman terhadap peserta didik, (2) kemampuan mengelola dan melaksanakan pembelajaran, (3) kemampuan memanfaatkan teknologi pembelajaran, (4) kemampuan melaksanakan evaluasi, dan (5) pengembangan potensi peserta didik sudah baik. Hal ini dapat dibuktikan dengan adanya aktivitas pembelajaran yang mampu menghidupkan suasana kelas, membuat peserta didik antusias dan bersemangat, menantang peserta didik untuk mau bertindak berpikir kreatif serta member kesempatan kepada peserta didik untuk mengemukakan gagasan, merancang, dan berkreasi. Dengan menggunakan metode yang bervariasi guru mampu menciptakan kegiatan pembelajaran yang kreatif pada mata pelajaran bahasa Indonesia di kelas V SDI Al-Muslimun.

Kendala-kendala yang dihadapi guru dalam menciptakan kegiatan pembelajaran yang kreatif pada mata pelajaran bahasa Indonesia pada kelas V di SDI Al-Muslimun Bunut Baok adalah sebagai berikut: (1) bahasa yang digunakan peserta didik masih menggunakan bahasa daerah; (2) adanya kedekatan antara guru dengan murid dari latar belakang tempat tinggal yang sama menjadi alasan para guru dengan peserta didik terkesan kurang serius dalam proses pembelajaran; (3) karakter yang berbeda dari masing-masing peserta didik; (4) tidak tersedianya media pembelajaran di sekolah; dan (5) kurangnya anggaran.

\section{Saran}

Berdasarkan hasil penelitian di atas, beberapa saran yang sebaiknya tindaklanjuti oleh kepada kepala sekolah untuk terus berusaha meningkatkan kinerja guru di SDI Al-Muslimun dengan meningkatkan berbagai macam kompetensi yang dimiliki khususnya kompetensi pedagogik guru dalam menciptakan kegiatan pembelajaran yang kreatif.

36 Jamal Ma'mur Asmani. 2012. 7 Tips Aplikasi PAKEM. Jogjakarta: Diva Press. hal. 198. 


\section{DAFTAR PUSTAKA}

Abdurrahman Shaleh. 2005. Pendidikan Agama dan Pengembangan Watak Bangsa. Jakarta: PT Raja Grafindo Persada.

Ahmad Susanto. 2016. Teori Belajar \& Pembelajaran di Sekolah Dasar. Jakarta: Prenada media Group.

Dendi Sugono. 2008. Kamus Besar Bahasa Indonesia Dengan EYD. Jakarta: PT Gramedia Pustaka Utama.

Hamzah B. Uno. 2011. Perencanaan Pembelajaran. Jakarta: PT Bumi Aksara.

Hamruni. 2012. Strategi Pembelajaran. Yogyakarta: Insan Madani.

Hamzah. 2012. Profesi Kependidikan Problema, Solusi dan Reformasi Pendidikan di Indonesia. Jakarta: Bumi Aksara.

Jamal Ma’mur Asmani. 2012. 7 Tips Aplikasi P AKEM. Jogjakarta: Diva Press.

Pupuh Fathurrohman. 2014. Strategi Belajar Mengajar. Bandung: Refika Aditama.

Mulyasa. 2007. Standar Kompetensi dan Sertifikasi Guru, Bandung: PT Remaja Rosdakarya.

Oemar Hamalik. 2006. Pendidikan Guru Berdasarkan Pendidikan Kompetensi, Jakarta: Bumi Aksara.

Ramayulis. 2016. Profesi dan Etika Keguruan. Jakarta: Kalam Mulia.

Saefudin Azwar. 2010. Metode Penelitian. Yogyakarta: Pustaka Pelajar.

Soetjiningsih. 2012. Psikologi Perkembangan Anak. Jakarta: PRENADA.

Utami Munandar. 2002. Kreativitas dan Keberbakatan Strategi Mewujudkan Potensi Kreatif dan Bakat. Jakarta: Gramedia Pustaka.

Utami Munandar. 2002. Kreativitas dan Keberbakatan Strategi Mewujudkan Potensi Kreatif dan Bakat, Jakarta: Gramedia Pustaka.

Zainal Aqib. 2009. Belajar dan Pembelajaran di Sekolah Dasar. Bandung: CV. Yrama Widya. 